\title{
Advancing Health Promotion Priorities: Stories of Capacity Building from the Canadian Heart Health Initiative (CHHI)
}

Faire avancer les priorités en matière de promotion de la santé : exemples de renforcement des capacités tirés de l'Initiative canadienne en santé cardiovasculaire (ICSV)

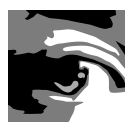

by S. MICHELLE DRIEDGER, PHD

Department of Community Health Sciences, University of Manitoba Winnipeg, $M B$

KERRY ROBINSON, MA

School of Geography and Earth Sciences, McMaster University Hamilton, ON

JOHN EYLES, PHD

School of Geography and Earth Sciences, McMaster University Hamilton, $\mathrm{ON}$ 
S. Michelle Driedger et al.

ADELE IANNANTUONO, PHD

Consultant, EP Solutions

Toronto, ON

ON BEHALF OF THE CHHDP STRATEGIC AND RESEARCH ADVISORY GROUPS:

Strategic Advisory Group: Catherine Donovan, Kelly McQuillen, Myrna Gough,

Scott McLean, P.J. Naylor, Kim Raine

Research Advisory Group: Ernest Khalema, Lori Ebbesen, Ken Fowler, Murray McKay,

Olive Moase, Barb Riley

\begin{abstract}
The purpose of this paper is to explore how public health professionals built capacity to carry out health promotion despite a low level of investment and competition for financial resources with acute-oriented healthcare services. Three data sources are used in this analysis: key-informant interviews with project participants, final reports from three provincial Heart Health projects in Canada (Prince Edward Island, Ontario and Manitoba) and major provincial health policy documents prior to and during each project. We use a narrative policy analysis to identify contextual factors influencing health promotion priority and progress through capacity building. Common capacity building themes emerged from the data despite the different contexts within which the projects were situated: building community trust and support, developing a linking system that promotes provincial partnerships and assisting in sustainability efforts by coordinating resources and efforts towards a common chronic disease prevention strategy. Each of these provincial projects overcame instances of resistance to advancing a health promotion agenda by concentrating on building relationships, by making better use of existing structures and organizations and by developing new productive unions that shared a primary prevention agenda.
\end{abstract}

\title{
Résumé
}

Cet article a pour but d'explorer comment les professionnels de la santé publique ont renforcé leurs capacités en vue de promouvoir la santé, et ce, malgré un faible niveau d'investissements et une concurrence avec les services de santé axés sur les soins actifs pour les ressources financières. Trois sources de données ont été utilisées pour cette analyse : des entrevues avec des intervenants clés participant au projet, les rapports finaux de trois projets provinciaux réalisés dans le cadre de l'Initiative canadienne en santé cardiovasculaire (Île-du-Prince-Édouard, Ontario et Manitoba) et des documents provinciaux clés sur les politiques de santé avant et pendant chaque projet. Nous utilisons une analyse de politiques narrative pour repérer les facteurs contextuels 
qui influencent les priorités et les progrès en matière de promotion de la santé par l'entremise du renforcement des capacités. Malgré les différents contextes dans lesquels les projets ont eu lieu, des thèmes communs se sont dégagés des données, notamment, bâtir la confiance et le soutien de la communauté, élaborer un système d'appariement qui favorise les partenariats provinciaux et participer aux efforts de durabilité en coordonnant les ressources et les efforts consacrés à l'élaboration d'une stratégie commune pour la prévention des maladies chroniques. Chacun de ces projets provinciaux a surmonté une certaine résistance pour assurer l'avancement des programmes de promotion de la santé en mettant l'accent sur l'établissement de relations, en faisant une meilleure utilisation des structures et organismes existants et en forgeant de nouvelles alliances productives qui partageaient un objectif de prévention primaire.

\section{$\boldsymbol{C}_{\text {here is a growing Consensus about the importance of Chronic }}$ disease prevention, as chronic diseases account for $70 \%$ of all deaths and over $153 \%$ of the economic burden of illness in Canada (PHAC 2001; Health} Canada 2002). Canada appears to be committed to health promotion, defined here as "the process of enabling people to increase control over and improve their health" (WHO 1986: iii). Health promotion in Canada is also based on a policy history that espouses the value of comprehensive primary prevention of chronic disease and population health strategies based on an understanding of multiple determinants of health and a diverse set of actions that involve multi-level (system/sector, community, individual), multi-channel (schools, workplaces, media) interventions using multiple strategies (e.g., strengthen community action/mobilization, build healthy public policy, create supportive environments, develop personal skills and reorient health services) (Hamilton and Bhatti 1996; Epp 1986; FPTACPH 1994; CPHI 2004). However, when the reality of health sector resource allocation is examined, prevention and promotion fare poorly, representing between $2 \%$ and $6 \%$ of provincial/territorial health expenditures (CIHI 2002). A recent study (Williamson et al. 2003) concluded that while Canadian provinces have health goals related to prevention and broad health determinants, regional-level policy makers have resisted a shift towards health promotion and continue to prioritize healthcare goals.

A review by Curtis and White (2002) suggests that the most frequently cited reasons for resistance to institutional or organizational change include increased stress; denial; self-interest; lack of understanding, trust or ownership; uncertainty; lack of motivation; different assessments or perceptions; and organizational culture. Resistance also grows out of a need to reconcile changes with existing beliefs, behaviours or actions when underlying value positions are challenged (Siebel 1996). For example, there is medical/institutional resistance to changes that would appear to 
take resources away from acute care services and reallocate them to primary prevention strategies (McKinley and Marceau 2000). This is particularly relevant in our study, as it is the public health system that is trying to find a more central place in the larger (and more institutionally dominant) healthcare system. In this paper, the groups under study are not part of the institutional structure of the healthcare sector; rather, these groups are part of the public and community health system working in direct competition with healthcare (acute care, primary care) for funds, resources and policy commitment for health promotion.

This paper investigates the contextual factors influencing the priority and progress of Heart Health promotion activities through the dissemination phase of the Canadian Heart Health Initiative (CHHI). The CHHI Dissemination Phase focuses on capacity building and dissemination processes for comprehensive health promotion. Health promotion capacity is the capability of an organization to promote health effectively, made up of multiple dimensions including will, knowledge, skills, partnerships, resources, infrastructure and leadership (Hawe et al. 1998; Goodman et al. 1998; Singapore Declaration 1998; Jackson et al. 1994). Capacity building aims to enhance the ability of an organization to plan, implement, evaluate and sustain health promotion efforts (Jackson et al. 1994; Schwartz et al. 1993).

Our focus in this paper is on these dimensions of capacity building as health promotion projects and public health staff strived to get health promotion onto provincial agendas through greater policy commitment. We present stories of capacity building among community and regional/local public health professionals that illustrate how health promotion priorities generally, and the CHHI specifically, have been advanced despite overall healthcare system resistance to change. Our analysis of three provinces - Prince Edward Island (PEI) 1996-2001, Ontario 1994-1998 and Manitoba 19962001 - examines how health promotion projects may overcome institutional barriers through capacity building when public health funding is a low priority.

\section{Methods}

This research represents one part of a larger research program, the Canadian Heart Health Dissemination Project (CHHDP), designed to draw lessons from the projects involved in the CHHI Dissemination Phase. The current analysis uses qualitative methods and a narrative policy approach that recognizes the importance of contexts and meaning (Yanow 1993) that underlie rhetoric. Context is often not explicitly stated within a particular text or report, yet is understood or taken as given through the language included or excluded (Stone 1997). Narrative analysis thus demonstrates that in language (text), facts and values are not meant to be separate. Values, though often left unstated, can be understood through a narrative by using analytic tools to uncover the explicit and implicit statements that shape the storyline. 
Stories are the main elements or messages presented through text (Roe 1994). We generate stories through collecting themes in data sources, using them to retell the common narrative. A narrative, however, is not only what is written or said but also what is left out. Elements that influence or motivate a policy are represented in the "struggle over ideas" that went into generating it (Stone 1997). The stories that run counter to it, or are omitted, are referred to as non-stories (Roe 1994). In combining stories and non-stories, metanarratives can be generated. Metanarratives allow for a retelling of the issue/key themes that can enable greater understanding and possibly new policy or programming action because they make explicit the underlying assumptions and values (the non-stories) as part of the new storyline (Roe 1994). Metanarratives are not intrinsic features of stories; rather, it is the analyst whose interpretation of multiple sources (e.g., multiple documents, or in this study, multiple documents and interviews) seeks to fill in the gaps of the implicit statements or unstated assumptions that are notably absent in a primary document source (e.g., a final report, a "white paper," etc.). Only through a critical reading of the available primary document text, in comparison with other texts that either seek to expand, critique or support the primary document, can some of these unstated assumptions be made explicit.

This narrative analysis of three completed CHHI provincial Heart Health projects demonstrates how these initiatives depict a rhetoric of (story) and resistance to (non-story) health promotion, and how these have been transformed into new realities of capacity building and coping strategies (metanarrative) to overcome the dominant acute health services discourse. Our analysis draws from three separate data sources for each province: key-informant interviews with project participants; final reports from the projects in PEI (Sweet et al. 2001), Ontario (Cameron et al. 1998) and Manitoba (Gelskey et al. 2001); and major provincial health policy documents in a five-year period prior to the start of each project (i.e., 1991-1996 in both PEI and Manitoba, and 1989-1994 in Ontario). By drawing on these multiple sources, using the $\mathrm{CHHI}$ provincial project final reports as the primary text, it is possible to explore the underlying values and assumptions. (Note: Four other provincial projects are still under study and, at the time of analysis, were not yet completed.)

Key-informant interviews were conducted with project members and stakeholders (total $n=40$ ) using a purposeful sampling approach to obtain a range of positions within research teams (investigator, research and intervention staff); individuals with a longer period of involvement in the project (two or more years); stakeholders from government (local, provincial), non-government and community organizations; and stakeholders with varied project roles (e.g., work group members, committee chairs, volunteers). The key-informant interviews included discussion of the following topic areas: definitions and measures by projects of key terms like "capacity building" and "dissemination"; effect of project research activities and interventions on capacity building within their respective study sites; understanding of the underlying context 
that had an impact on projects throughout their duration (e.g., regionalization); and finally, participant reflections on the conditions and characteristics of effective capacity building and dissemination of Heart Health promotion programs. For the purpose of this analysis, we draw on interview reflections of capacity building conditions and characteristics and contextual factors that influenced the nature and shape of the provincial Heart Health projects.

The project final reports describe each provincial project's research and intervention activities, context, facilitators and barriers to capacity building and dissemination, and research findings, both qualitative and quantitative in nature. We draw on these documents to inform our understanding of capacity building processes, outcomes and factors affecting it. Finally, these data sources were supplemented by a review of major provincial health policy documents. All provincial health policy documents that related to dissemination and capacity building, health promotion and chronic disease prevention, health system reform or state-of-health-system reports, and health goal documents or plans were selected from within a time-frame of five years prior to each provincial dissemination phase and throughout the CHHI Dissemination Phase. Policy document inventories were created by provincial project researchers in consultation with provincial health policy makers for each province. Policy documents were examined for the language used to frame health system priorities and issues, contextual factors influencing each provincial health system and the development and directions of government policy initiatives for health promotion in general and for chronic disease prevention specifically.

All the interview transcripts, provincial policy documents and project final reports were imported into NUD*IST qualitative software for thematic analysis using a coding scheme to index, search, summarize and analyze the data (Patton 2002). Analysis included searches both within and across provincial cases based on thematic frequency and patterns of similarities and differences. To develop the initial coding scheme, two coders analyzed separately and then compared the results of a sample of interviews and documents for key themes guided (though not limited) by a set of a priori themes stemming from the research questions and a review of the literature (on capacity and dissemination processes and outcomes). Any disagreements in coding were resolved through discussions. On the final coding scheme, we then employed a test of intercoder dependability (consistency between coders for very detailed coding: down to the level of subthemes, 69\%, and agreement for broad thematic coding, 80\%). Intra-rater tests (individual consistency in code-recode of interviews) were also employed, reaching 80\% (Miles and Huberman 1994).

We began with an intra-analysis of documents, and then of interviews for each province, followed by a synthesis of key themes between documents and interviews before completing a comparative inter-case analysis. This analysis evolved through iteration and team discussion in which team members sought to challenge interpreta- 
tions to minimize bias through expectancy effect (tendency for researchers to obtain results they expect, not simply because they have correctly anticipated the response but because they have helped to shape that response through their expectations) (Bernard 1995). We validated our analysis (Cresswell 2003) by providing summaries of our interpretations to interview respondents and project representatives by way of a fax-back feedback form (completed by $48 \%$ of provincial project respondents).

Our study methodology is not without its limitations. It is possible that the timing of our interviews - occurring some time after one provincial project (Ontario's) ended - could have yielded a re-interpretation of the reports now that the reports were disseminated. However, the interviews with researchers from the projects, as well as volunteers, partners and intervention staff who were not responsible for the writing of final reports, helped serve as a check of multiple stories coming from different sources. While different perspectives of stakeholders, researchers and documents rarely perfectly overlap, there were no outright conflicts; rather, integrating these multiple perspectives provided a more complete, nuanced and perhaps "messy" understanding of capacity building experiences and outcomes. Our use of the member-checking process ensured that our interpretation of explicit and implicit statements of documents, interview texts and final reports was consistent with the understanding of interview participants and our provincial project advisory group in capturing the overall experience of each provincial project.

Overall, our analysis found that key-informant interview conversations make explicit the resistance and obstacles that are implicit or unstated assumptions embedded in the project's written final report. In other words, by comparing the different sets of themes, we found that the underlying assumptions implicit in the report (the non-story) were often the explicit story of the interviews. Moreover, the context and rhetoric in health policy documents five years prior to a provincial project highlight the unstated assumptions (the non-story) of project final reports. The value-added dimension of our policy analysis is its combination of documentary analysis and interviews with actors involved in the development of those documents, something not typically done in narrative policy analysis. This method provides for a more comprehensive view of health promotion progress.

\section{Results}

\section{Prince Edward Island Heart Health Program (PEI HHP, 1996-2001)}

The PEI HHP was a joint venture between the Eastern Kings Health Region and PEI's Department of Health and Social Services. Health promotion programming was carried out by staff and volunteer-led activities in a coalition to reduce cardiovas- 
cular disease risk factors in the local community. Sustainability was a major concern. It was the motivation for volunteer involvement as well as a framework for all coalition decisions (see PEI Stories, Table 1).

From our analysis, two main contextual factors influenced the PEI HHP: (1) health reform, with an emphasis on community-based services and (2) the drive for cost-effective medical services with sustainable resources. Policy documents prior to the start of the dissemination project (PEI 1992, 1993, 1996) laid the foundation for health promotion and disease prevention as solutions to financial constraints within the healthcare system. Moreover, regionalization in PEI influenced the shape of the dissemination project by focusing on community-based projects, which indirectly encouraged personal responsibility for health. In theory, small social service programs and prevention programs were on equal footing with hospitals, but programs competed for funding. In a budget-constrained system, medical care still dominated as a health system priority.

The interviews revealed sources of resistance to the dissemination project not found in project final reports (see PEI Non-stories, Table 1). First, several respondents commented on the challenges in gaining broader community trust in the project. At the outset there was a general distrust towards community-based research projects that came and went. Consequently, one of the primary conditions for community participation was to have the Region guarantee sustainability by committing funds for a health promotion staff position after the project concluded. Sustainability is one central, anticipated outcome of capacity building efforts. Second, to counterbalance community resistance and enhance skills, the project was designed around a participatory action research model, which created a structure of community volunteers paired with research staff members on a Community Research Advisory Team (CRAT). The CRAT volunteers shared decision-making power with staff from the Department of Health and Social Services over community projects and research activities. Effective planning, implementation and evaluation skills and decisions through partnerships are three other key outcomes of capacity building efforts.

A partnership was built where there could be ongoing communication. What the health system wanted was feedback and information, input from the community. What the community wanted was more commitment and health promotion action from the region. And what was built was a structure in which community volunteers would link with health professionals in working groups. (Interview)

Despite this success in achieving community participation, there was yet a larger challenge. There was strong resistance from physicians and community residents towards health promotion programs. Health promotion interventions were viewed as 
a redirection of scarce funds from acute hospital-based services (i.e., the sick) to health promotion activities (i.e., the healthy); this resistance could be interpreted as a desire to protect already limited medical care dollars:

Getting your healthcare workers on board ... that was hard for me because I was an acute care nurse, and that's the environment I left, from people who are critically ill to people that are critically well, so it was hard to get health professionals on board .... (Interview)

Our analysis of these themes (stories) and assumptions (non-stories) demonstrates that community values, trust and partnerships were seen as the capacity building foundation for overcoming institutional and community resistance (see PEI Metanarrative 2, Table 1). Indeed, there was a much stronger concentration on process (community participation), values (gaining trust and commitment) and ideals (framed within a larger determinants-of-health view) in the final report. By contrast, the interviewees, drawn from a larger base of staff and volunteers, focused more on concrete strategies for effective health promotion practice. A strong community structure was required for health promotion initiatives; thus, a linking system between paid staff, community groups and volunteers was pivotal to achieving some sustainability of efforts (also see PEI Metanarratives 1-2):

You need one person who's responsible, and I believe that's the reason why our project is going so well here is that we have a paid staff who is responsible, we know who to go to and we know who to get information from, and we know that they've done a good job in the past. (Interview)

Thus, the nature of interactions that allowed the PEI HHP to overcome resistance was characterized by a two-way exchange between volunteers and paid staff through regular communication, training in research and programming, and collaboration.

\section{Canadian Heart Health Initiative Ontario Project (CHHIOP, 1994-1998)}

CHHIOP targeted all of the then 42 local public health units mandated provincially to enhance healthy lifestyles at the community level. Given the province's investments in capacity building and resource system development in the 1990s, the Ontario project focused on research/monitoring and linking provincial and regional partners to reflect on research results.

Several contextual factors were at play during CHHIOP. First, prior to CHHIOP, Ontario's health policy environment was already favourable towards health promotion and chronic disease prevention as a cost-effective alternative to traditional 
TABLE 1. Provincial stories, non-stories and metanarratives

\begin{tabular}{|c|c|c|}
\hline PEI (I996-200I) & Ontario (1994-1998) & Manitoba (1996-200I) \\
\hline $\begin{array}{l}\text { Stories } \\
\text { I. Sustainable community mobi- } \\
\text { lization is key to undertake } \\
\text { chronic disease prevention } \\
\text { programming. } \\
\text { 2. Must have flexible structure } \\
\text { and champions to cope with } \\
\text { change. }\end{array}$ & $\begin{array}{l}\text { I. A strong provincial govern- } \\
\text { ment role is key to enhancing } \\
\text { health promotion priority set- } \\
\text { ting and funding. } \\
\text { 2. Public health departments are } \\
\text { ideal to deliver programs. } \\
\text { 3. A central resource system } \\
\text { facilitates programming. }\end{array}$ & $\begin{array}{l}\text { I. Only multi-level (regional, } \\
\text { provincial) strategies can pre- } \\
\text { vent heart disease. } \\
\text { 2. Heart health promotion is } \\
\text { best delivered locally. } \\
\text { 3. Community involvement } \\
\text { means that health promotion } \\
\text { can be delivered at low cost. }\end{array}$ \\
\hline $\begin{array}{l}\text { Non-Stories } \\
\text { I. Securing dedicated funds for } \\
\text { health promotion is seen as a } \\
\text { redirection of funds from the } \\
\text { sick to the healthy. } \\
\text { 2. Volunteers can fulfill many } \\
\text { tasks, but they need to be } \\
\text { linked with paid staff to deliver } \\
\text { effective and sustainable pro- } \\
\text { gramming. }\end{array}$ & $\begin{array}{l}\text { I. Community support, training } \\
\text { and budgets are needed to } \\
\text { build programming capacity. } \\
\text { 2. Sustainability is not possible } \\
\text { with the province as main } \\
\text { decision-making player (owing } \\
\text { to funding shifts). } \\
\text { 3. Champions at all levels are } \\
\text { needed to coordinate priori- } \\
\text { ties and resources. }\end{array}$ & $\begin{array}{l}\text { I. Everyone is responsible for } \\
\text { heart health. } \\
\text { 2. Dissemination and capacity } \\
\text { building are dependent upon } \\
\text { resource allocation within the } \\
\text { healthcare system. } \\
\text { 3. Budgetary constraints and } \\
\text { health reform directs funding } \\
\text { priorities to existing (acute } \\
\text { care) services. }\end{array}$ \\
\hline $\begin{array}{l}\text { Metanarratives } \\
\text { I. Effective community-based } \\
\text { programs can be a low-cost } \\
\text { solution to rising health costs, } \\
\text { but must link staff and volun- } \\
\text { teers as genuine partners. } \\
\text { 2. Sustainability requires: (a) com- } \\
\text { munity buy-in, commitment } \\
\text { and ownership of the means } \\
\text { to improve health outcomes } \\
\text { and (b) dedicated resources to } \\
\text { sustain key activities. }\end{array}$ & $\begin{array}{l}\text { I. Individual disease strate- } \\
\text { gies must be merged into a } \\
\text { chronic-disease approach that } \\
\text { addresses shared risk factors. } \\
\text { 2. A coordinated linking system } \\
\text { that connects provincial and } \\
\text { regional public health depart- } \\
\text { ments is needed for sustain- } \\
\text { ability. }\end{array}$ & $\begin{array}{l}\text { I. Traditional healthcare serv- } \\
\text { ices are not enough to keep } \\
\text { Manitobans healthy. } \\
\text { 2. Health promotion must be } \\
\text { part of a community-govern- } \\
\text { ment strategy to build capacity. } \\
\text { 3. Strong regional and NGO } \\
\text { partnerships that pool } \\
\text { resources are needed to } \\
\text { advance chronic disease } \\
\text { prevention and public health } \\
\text { strategies. }\end{array}$ \\
\hline
\end{tabular}

healthcare spending (Ontario Ministry of Health 1989, 1993, 1994). Second, within CHHIOP's second year of operation, Ontario's governing party changed from the New Democratic Party (socialist left) to the Progressive Conservative Party (conservative right). Under a Conservative "common sense" revolution for healthcare in Ontario, $100 \%$ of public health services funding was downloaded from the provincial to municipal governments (Elliott et al. 2000). This was modified to a 50-50 cost-sharing arrangement, but provincial control over the public health mandate was retained. 
Third, in 1997, the Ministry of Health released its Mandatory Health Programs and Services Guidelines for public health departments, which targeted integrated disease prevention, health promotion and protection.

These contextual factors are present in the CHHIOP Final Report (Cameron et al. 1998) and interviews. Population health approaches were facilitated through the creation of provincial resource centres, including the Heart Health Resource Centre, with its mandate to build capacity and disseminate information and resources to support health promotion efforts of public health departments (see Ontario Stories 1-3, Table 1). Capacity building was also facilitated through CHHIOP's Project Advisory Group, consisting of several public health units, health ministry staff, resource centres and research team members. The Project Advisory Group served as a research-policy-practice interface by feeding back research results to various stakeholder groups. Combined, these activities served to create partnerships and infrastructure, two important dimensions to support capacity building and enhance health promotion activities.

However, while there was strong government support of health promotion, implementation of public health programs was difficult given insufficient resources and multiple competing disease strategies. Resistance from the provincial government, in the form of lack of coordinated leadership for public health, had an impact on local public health units. Competing budgetary and political priorities, lack of coordination in the public health system, insufficient staff or high turnover, varying levels of partnership development and tensions created due to the change in provincial government all posed internal barriers in the system (see Ontario Non-stories 1-3). This lack of coordination and competing priorities were common to several limited and short-term funding commitments for individual disease strategies:

I think something that's made it more difficult for us from a provincial level is there's a number of risk factors - they all contribute to heart disease, to diabetes, to asthma, to stroke.... There wasn't enough money sometimes ... [and] it's a lot of the same stuff, so some of the partners and sometimes public health would run off in that direction and quickly do a [funding] proposal for diabetes ... or asthma ... or stroke.... It was all lifestyle related, and one good thing was Heart Health money was sustainable for at least five years [compared to] all those other one-offs. (Interview)

Together, these themes (stories) help reveal the assumptions (non-stories) being made about Heart Health promotion in Ontario. The resource struggles and structural changes in the public health system (the non-stories) flowed from public health's not being a core part of the traditional healthcare system. In order to overcome resource struggles and structural changes in the Ontario public health system, which was institutionally and financially separate from the healthcare sector, a more strategic capacity 
building approach was advanced by provincial and regional public health stakeholders (NGOs, resource centres, government) to coordinate a centralized provincial linking system integrating individual disease strategies into a chronic disease strategy to address shared risk factors. This was evident through an increase in the number of provincial and regional partnerships and coalitions that permitted the emergence of interdisciplinary teams working towards a common cause (see Robinson et al. 2005); these are all necessary dimensions of capacity building through a common vision. Moreover, along with other provincial initiatives, such as the development of a provincial resource system (a series of linked provincial level resource organizations to provide coordinated training, technical assistance and access to best practices), CHHIOP helped lay the groundwork in Ontario for deployment of resources for integrated Heart Health programming and, in essence, chronic disease prevention (see Metanarratives 1-2):

The relationship between CHHIOP and the Health Promotion and Public Health Branches continued after the dissemination project ended, to the point where we - the CHHIOP research team - became advisers to the Ministry of Health in the development and shaping of the Ontario Heart Health Program, which is currently on the ground in Ontario - where, after CHHIOP finished, the Ministry allocated $\$ 17$ million across five years to every health unit in the province to continue their Heart Health promotion. (Interview)

In Ontario, the nature of the interactions between provincial and regional leaders generated a stronger commitment to coordination of health promotion strategies, enhanced health promotion funding and central resource system support. The ability of such a partnership structure to support local planning implementation, evaluation and sustainability of health promotion efforts grew out of a strong commitment to building capacity at a systemwide level.

\section{Manitoba Heart Health Project (MHHP, 1996-2001)}

The MHHP was established as a community-driven initiative serving as an arm'slength "linking agent" to four rural community committees. The central contextual factor for Manitoba was major health reform in 1996, during the initiation of the MHHP. At this time, responsibility for decision-making, planning and delivery of programs and services was decentralized from Manitoba Health to Regional Health Authorities (RHAs). Manitoba Health was left with the responsibility for policy development and implementation, program development, development and distribution of resources and advice to RHAs with respect to program planning and research. There was little integration between RHAs and Manitoba Health; RHAs were now 
responsible for program delivery, yet Manitoba Health controlled the level of funding (Hurley et al. 1994). In fact, Sutcliffe and colleagues (1997) argued that RHAs suffered because of financial constraints, lack of political will and a continued focus on acute care issues.

These contextual factors underlie the messages of the MHHP Final Report (Gelskey et al. 2001), which emphasizes that heart health promotion is not a government but rather a community responsibility, and that a multiple risk factor approach is needed (see Manitoba Stories 1-2). One of the ways this was accomplished was through the creation of community committees in these rural sites, consisting primarily of volunteers and a minimally paid community coordinator (paid eight hours a week but dedicating many more hours). These community committees interacted closely with the provincial research team to develop action plans for the year and annual evaluations; these were used to garner expanded resources to support programming efforts (Robinson et al. 2005). Again, through these research team-community mentoring relationships, the community committees developed the skills to undertake evidence-based planning and implementation as well as acquire grant funding to sustain their health promotion efforts. As such, the MHHP focus on volunteer-based ownership of Heart Health promotion activities resulted in low-cost interventions (Manitoba Story 3):

At a health region level, we now have concrete evidence that we can do it. We can mobilize communities. We have done it 11 times.... When you say to somebody, here's this community over here, here's 30 activities at $\$ 5$ a head in a region, for $\$ 40,000$ a year, that's 8000 people reached; you're running 40 programs a year. They can't even hire a staff person for $\$ 40,000$ a year. (Interview)

Underlying these themes are values and assumptions, such as "heart health promotion is best delivered locally" and "heart health is the responsibility of everyone," which effectively remove provincial government accountability for primary prevention. The resistance to these ideas is manifest in the reality that the RHAs are left to determine what part of their funding envelope will be used for acute care services vs. health promotion. Provincial inaction on health promotion was implicitly revealed through the challenges faced by project participants. First, because there was very little money and limited provincial support for health promotion, many RHAs refocused on issues of traditional acute healthcare as opposed to health promotion (see Manitoba Non-stories 2-3). Second, following health reform many of the partnerships and agreements that the MHHP had arranged with the province and RHAs shifted because boundaries were redrawn, and in some cases responsibilities completely changed:

... when we started off with the health regions ... we were meeting with people from the old regions when we were setting up.... So later what we 
encountered was a tremendous disarray in personnel. There was no team left in those regions. People got demoted, people lost their jobs and people came into jobs that had never been there before. So the context was not really there to support us. The new regions had absolutely no allegiance to us. They didn't even know [MHHP] existed. (Interview)

In the Final Report (Gelskey et al. 2001), a new storyline emerges that acute care services are insufficient to keep Manitobans healthy (see Manitoba Metanarrative 1). Interview texts reveal a potential strategy for making progress against difficult odds: strong regional and non-governmental organization partnerships can build capacity to gain the visibility required to get health promotion back on the provincial agenda. Health reform necessitated that members of the MHHP take a leading role in facilitating and building an alliance of NGOs (e.g., Heart and Stroke Foundation, Cancer Society, Diabetes Association), the Chronic Disease Prevention Alliance, to coordinate chronic disease approaches and capacity support at a provincial level (Metanarratives 2-3):

Health reform changed some of that.... I think that if we hadn't had that fearsome reaction ... we might not have been so interested in creating, in conceptualizing the ideal Alliance. I think the Alliance will be far, far more influential than any public health unit.... The Alliance is bringing together organizations and resources. That kind of communication didn't happen before. (Interview)

The nature of the interactions in Manitoba to overcome resistance was twofold. First, Manitoba's community committees linked the provincial research team with local communities to identify priorities for programming and resource use. In fact, through MHHP training and technical assistance, the rural community committees developed grant-writing skills that resulted in new in-kind contributions in addition to MHHP funding (Gelskey et al. 2001). Second, the MHHP partnered with NGOs to form an alliance for advocacy and system development in the absence of a strong provincial commitment to a health promotion mandate and resources. Combined, these new capacity building skills and partnerships served to create a structure through the Alliance to increase government commitment and the sustainability of health promotion.

\section{Discussion and Conclusion}

Each project experienced a somewhat different social, political and economic provincial context within which to carry out health promotion dissemination. Yet, there are some similarities in provincial health promotion rhetoric: namely, a shift from "health 
as a government responsibility" to "health as a community or individual responsibility." In addition, there was a consistent theme of cost constraint, where health promotion was seen as a possible long-term solution to rising healthcare costs. However, the infrastructure for pursuing and adopting a health promotion approach appears to remain in competition with medical/healthcare sector approaches. Legowski and McKay's (2000) examination of the history of Canadian health policy confirms these patterns of a shift towards health promotion in national health policy, yet continued marginalization of health promotion (and health promotion capacity) due to the dominance of healthcare issues.

What is demonstrated by our analysis is how these individual provincial projects interacted with communities, organizations and governments to contribute to health promotion capacity and overcome resistance by securing the commitment to support health promotion priorities. Each project faced opposition from different sources. The PEI project met with resistance from the Eastern Kings community and healthcare providers based on lack of trust, uncertainty about sustainability and a perception that health promotion resources were being redirected from the healthcare system. In Ontario, public health units struggled at the systems level through a complex organizational structure and lack of coordination within the Ministry of Health. These factors created funding tensions and competing priorities at the local public health level. Manitoba experienced resistance through a lack of support and commitment to health promotion on the part of the provincial government and the newly formed Regional Health Authorities. This opposition was rooted in the stress on the local/regional and provincial health systems and uncertainty caused by significant reform.

The unifying strategy that overcame these sources of resistance was capacity building. PEI coped by building community trust and support through its participatory action research with joint government, research and community involvement and incorporating a sustainability component. Its success in the Eastern Kings Region was used by project-related Department of Health contacts as a springboard to garner support for a provincewide Strategy for Healthy Living.

In Ontario, the lack of coordination among provincial and local systems is being addressed through partnering among the Ministry of Health, provincial NGOs, resource centres, public health units and regional coalitions in the Ontario Heart Health Program (OHHP). These partners have recognized that health promotion would be better advanced if resources and efforts were coordinated provincially as an integrated chronic disease prevention strategy. Thus, the Ministry of Health has renewed funding for the OHHP as part of a transition to chronic disease prevention and healthy living (Government of Ontario 2002).

Manitoba coped with the lack of structural support and commitment to Heart Health promotion by pursuing non-traditional partnerships. First, the MHHP built connections with the RHAs and trust among the community committees. Second, 
it got provincial NGOs on board to coordinate and pool resources and strategies, which led to Manitoba Health's joining the Chronic Disease Prevention Alliance. This Alliance has since been successful in advocating for and working with the provincial government to launch a provincewide Chronic Disease Prevention Initiative with funding for community committees.

In all these cases, resistance was at least partially overcome through capacity building. By enhancing will, skills, knowledge, partnerships, resources, infrastructure and leadership, the public health sector was better equipped - at the community and provincial levels - to plan, implement, evaluate and sustain health promotion efforts.

In all three cases, health reform or system change played a role in shaping these dissemination projects, but to varying degrees. All three provinces faced a restructuring of health funding in which responsibilities were devolved, but the provincial health ministries still largely controlled the pursestrings and mandate. These were the realities. Health promotion and capacity literature has increasingly reflected the critical role of external contextual and policy environment factors in influencing health promotion efforts (Green and Kreuter 2005; Foster-Fishman et al. 2001). Each of the provincial projects studied contributed to building capacity through relationships, by tapping into existing structures and organizations and by developing new productive unions that shared joint agendas for primary prevention. The emphasis on medical care priorities was resisted, and health promotion capacity was built in all three provinces to enhance the health of their populations.

Our analysis suggests that within the context of provincial health systems that are under continuous financial stress, reform or restructuring, health promotion priorities have good potential for advancement through capacity building that focuses on partnerships and creation of sustainable infrastructure (joint government-community coalitions or committees). Indeed, this finding is supported by existing capacity literature that highlights the central facilitating role of external partnerships and joint collaboration for health promotion (Joffres et al. 2004; Riley et al. 2001). Within environments and organizations that are resistant to change, establishing trust, emphasizing community or stakeholder participation and working towards integration, or at least coordination of existing efforts (e.g., disease strategies, organizational mandates), is a way forward for enhancing commitment to health promotion in a system that is centred on medical care.

Correspondence may be directed to: S. Michelle Driedger, Department of Community Health Sciences, University of Manitoba, S113 - 750 Bannatyne Avenue, Winnipeg, MB R3E 0W3; tel.: 204-789-3936; fax: 204-789-3905; e-mail: Michelle_Driedger@UManitoba.ca.

\section{ACKNOWLEDGMENTS}

The authors would like to acknowledge that this work would not have been possible without the 
research, intervention efforts and interpretations of the provincial dissemination project teams: Prince Edward Island Heart Health Program, Manitoba Heart Health Project and Canadian Heart Health Initiative - Ontario Project. This research is funded by the Canadian Institutes of Health Research.

\section{REFERENCES}

Bernard, H.R. 1995. Research Methods in Anthropology - Qualitative and Quantitative Approaches (2nd ed.). Walnut Creek: Altamira Press.

Cameron, R., S. Elliott, S.M. Taylor, R. Walker, M. Gough, C. D’Cunha, R. Schabas and D. Mowat. 1998. CHHIOP Final Report. Ottawa: National Health Research and Development Program.

Canadian Institute of Health Information (CIHI). 2002. Preliminary Provincial and Territorial Government Health Expenditure Estimates, 1974/75-2002/03. Ottawa: Author.

Canadian Population Health Initiative (CPHI). 2004. Improving the Health of Canadians. Ottawa: Canadian Institute for Health Information.

Creswell, J.W. 2003. Research Design: Qualitative, Quantitative, and Mixed Methods Approaches (2nd ed.). Thousand Oaks, CA: Sage Publications.

Curtis, E. and P. White. 2002."Resistance to Change: Causes and Solutions." Nursing Management 8: $15-20$.

Elliott, S.J., S.M. Taylor et al. 2000. "Restructuring Public Health in Ontario: Implications for Heart Health Promotion." Canadian Journal of Public Health 91: 94-96.

Epp, J. 1986. Achieving Health for All: A Framework for Health Promotion. Ottawa: Ministry of Supply and Services Canada.

Federal, Provincial and Territorial Advisory Committee on Population Health (FPTACPH). 1994. Strategies for Population Health: Investing in the Health of Canadians. Ottawa: Health Canada.

Foster-Fishman, P.G., S.L. Berkowitz, D.W. Lounsbury, S. Jacobson and N.A. Allen. 2001.

"Building Collaborative Capacity in Community Coalitions: A Review and Integrative Framework." American Journal of Community Psychology 29(2): 241-58.

Gelskey, D.E., D. Harvey, E. Hook, M. McKay and D. Cepanec. 2001. Manitoba Heart Health Project, Dissemination Research Report: Enhancement of Rural Community Committee Capacity for Heart Health Promotion. Submitted to National Health Research and Development Program, Health Canada, Ottawa, Canada.

Goodman, R.M., M.A. Speers, K. McLeroy, S. Fawcett, M. Kegler, E. Parker, S.R. Smith, T.D. Sterling and N. Wallerstein. 1998. "Identifying and Defining the Dimensions of Community Capacity to Provide a Basis for Measurement." Health Education and Behaviour 25(3): 258-78. Government of Ontario. 2002 (November 19). “Eves Government Invests \$29 Million in Disease Prevention." Press release.

Green, L.W. and M.W. Kreuter. 2005. Health Promotion Planning: An Educational and Ecological Approach (4th ed.). New York: McGraw-Hill.

Hamilton, N. and T. Bhatti. 1996. Population Health Promotion: An Integrated Model of Population Health and Health Promotion. Ottawa: Health Canada, Health Promotion Development Division. 
Hawe, P., L. King, M. Noort, S. Gifford and B. Lloyd. 1998. “Working Invisibly: Health Workers Talk about Capacity-Building in Health Promotion." Health Promotion International 3(4): 285-95. Health Canada. 2002. Economic Burden of Illness in Canada, 1998. Ottawa: Author.

Hurley, J., J. Lomas et al. 1994. "When Tinkering Is Not Enough: Provincial Reform to Manage Health Care Resources." Canadian Public Administration 37: 490-514.

Jackson, C., S.P. Fortmann, J.A. Flora, R.J. Melton, J.P. Snider and D. Littlefield. 1994. “The Capacity-Building Approach to Intervention Maintenance Implemented by the Stanford Five-City Project." Health Education Research 9(3): 385-96.

Joffres, C., S. Heath, J. Farquharson, K. Barkhouse, C. Latter and D.R. MacLean. 2004.

"Facilitators and Challenges to Organizational Capacity Building in Heart Health Promotion." Qualitative Health Research 14(1): 39-60.

Legowski, B. and L. McKay. 2000. Health beyond Health Care: Twenty-five Years of Federal Health Policy Development. Ottawa: Canadian Policy Research Networks Discussion Paper No. HI04.

McKinlay, J.B. and L.D. Marceau. 2000. “To Boldly Go.” American Journal of Public Health 90: 25-33.

Miles, M.B. and A.M. Huberman. 1994. Qualitative Data Analysis (2nd ed.). Thousand Oaks, CA: Sage Publications.

Ontario Ministry of Health. 1989. A Vision of Health. Toronto: Premier's Council on Health Strategy.

Ontario Ministry of Health. 1993. Opportunities for Health: Promoting Heart Health. Report of the Chief Medical Officer of Health. Toronto: Author.

Ontario Ministry of Health. 1994. Health for All Ontarians: A Provincial Dialogue on the Determinants of Health. Toronto: Premier's Council on Health, Well-being and Social Justice.

Ontario Ministry of Health. 1997. Mandatory Public Health Programs and Services Guidelines.

Toronto: Public Health Branch.

Patton, M.Q. 2002. Qualitative Research and Evaluation Methods (3rd ed.). Thousand Oaks, CA: Sage Publications.

PEI. 1992. PEI Task Force on Health Reform: A Vision for Change. Charlottetown: Prince Edward Island Cabinet Committee on Government Reform.

PEI. 1993. PEI Health Transition Team on Health Reform. Partnerships for Better Health.

Charlottetown: Department of Health and Social Services.

PEI. 1996. Circle of Health: PEI's Health Promotion Framework. Charlottetown: PEI Health and Community Services.

Public Health Agency of Canada (PHAC). 2001. Major Chronic Diseases Surveillance On-line. Retrieved March 26, 2007. <http://dsol-smed.phac-aspc.gc.ca/dsol-smed/mcd-smcm>.

Riley, B.L., S.M. Taylor and S.J. Elliott. 2001."Determinants of Implementing Heart Health Promotion Activities in Ontario Public Health Units: A Social Ecological Perspective." Health Education Research 16(4): 425-41.

Robinson, K., S.M. Driedger, S.J. Elliott and J. Eyles. 2005. “Using Linking Systems to Build Capacity and Enhance Dissemination in Heart Health Promotion: A Canadian Multiple Case Study." Health Education Research 20(5): 499-513.

Roe, E. 1994. Narrative Policy Analysis: Theory and Practice. Durham, NC: Duke University Press. 
Schwartz, R., C. Smith, M.A. Speers, L.J. Dusenbury, F. Bright, S. Hedlund, F. Wheeler and T.L. Schmid. 1993. "Capacity Building and Resource Needs of State Health Agencies to Implement Community-Based Cardiovascular Disease Programs." Journal of Public Health Policy 14(4): 48094.

Siebel, W. 1996. "Successful Failure: An Alternative View on Organizational Coping." American Behavioral Scientist 39: 1011-24.

The Singapore Declaration. 1998 (September 2). Forging the Will for Heart Health in the Next Millennium. Declaration of the Advisory Board of the Third International Heart Health Conference, Singapore. Singapore National Heart Association.

Stone, D. 1997. Policy Paradox and Political Reason (2nd ed.). New York: HarperCollins. Sutcliffe, P.A., R.B. Deber et al. 1997. "Public Health in Canada: A Comparative Study of Six Provinces." Canadian Journal of Public Health 87: 246-49.

Sweet, L., R. White et al. 2001. Canadian Heart Health Initiative - PEI Project Dissemination Phase. Charlottetown: University of PEI Department of Health and Social Services.

Williamson, D.L., C.D. Milligan, B. Kwan, C.J. Frankish and P.A. Ratner. 2003. "Implementation of Provincial/Territorial Health Goals in Canada." Health Policy 64: 173-91.

World Health Organization (WHO). 1986. Ottawa Charter for Health Promotion. Ottawa: Canadian Public Health Association.

Yanow, D. 1993."The Communication of Policy Meaning: Implementation of Interpretation and Text." Policy Sciences 26: 41-61. 